\title{
Key Plant, Key Pests: Camellia ${ }^{1}$
}

\section{Juanita Popenoe, Caroline R. Warwick, and Brian Pearson ${ }^{2}$}

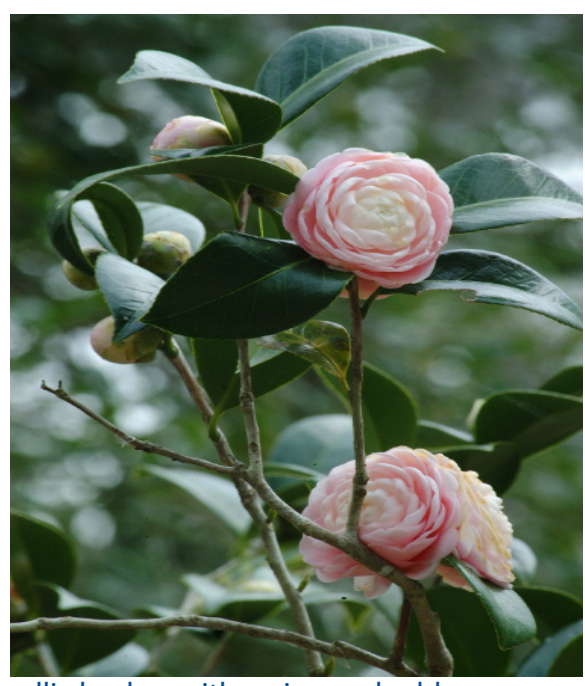

Figure 1. Camellia bushes with various color blooms. Credits: UF/IFAS

\section{Key Plant: Camellia}

Camellias are flowering plants that are common in

Southern landscapes. Camellia plants are commonly grown as a shrub in Florida, with the most common species being Camellia japonica and Camellia sasanqua, but can also be found throughout the US in USDA hardiness zones 7 to 9 (United States National Arboretum 2007). Camellia varieties range in plant size and come in a large assortment of flower colors, sizes, and forms (Figure 1,2). Camellias grow well in partial shade, are fairly drought tolerant, prefer fertile, well-drained soils, and adapt well to growing in containers; however, C. sasanqua are better adapted to growing in full sun (Brown 2015).

\section{Key Pests: Camellia}

This series of Key Plant, Key Pests publications is designed for Florida gardeners, horticulturalists, and landscape professionals to help identify common pests associated with common Florida flora. This publication, the second in the Key Plant, Key Pests series, helps identify the most common pests found on the camellia.

This publication provides information and general management recommendations for algal leaf spot, dieback, twig blight or canker, flower blight, wet root rot diseases, root rots, aphids, scale, spider mites, and nutrient deficiencies. For a more comprehensive guide of woody ornamental insect management, download the current Professional Disease Management Guide for Ornamental Plants or the Integrated Pest Management in the Commercial Ornamental Nursery Guide.

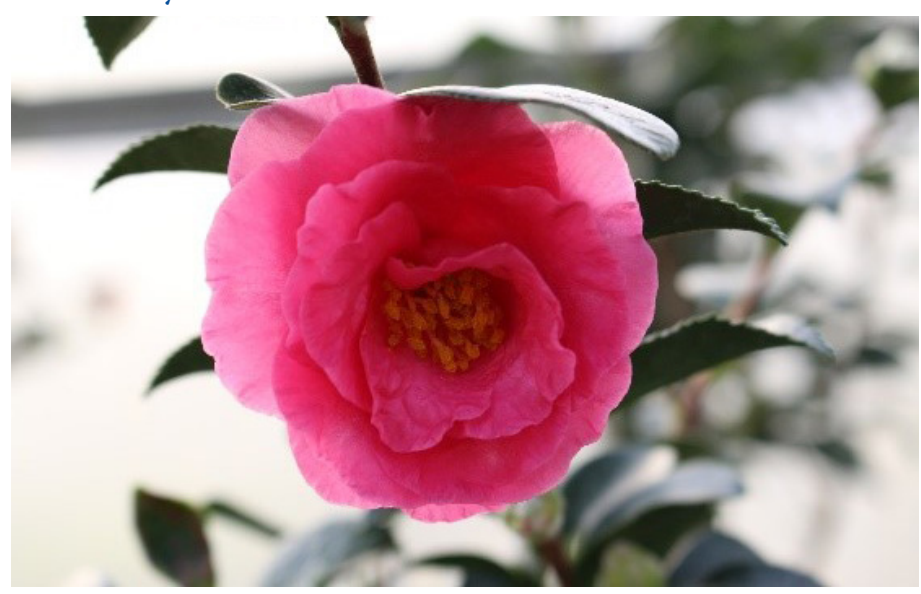

Figure 2. Camellia flowers come in a variety of colors, including the popular bright pink.

Credits: Caroline Roper, UF/IFAS

1. This document is ENH1294, one of a series of the Environmental Horticulture Department, UF/IFAS Extension. Original publication date June 2018. Visit the EDIS website at http://edis.ifas.ufl.edu.

2. Juanita Popenoe, multi-county commercial fruit production agent IV; Caroline Roper Warwick, science communication specialist; and Brian Pearson, assistant professor; Mid-Florida Research and Education Center, UF/IFAS Extension, Apopka, FL 32703.

The Institute of Food and Agricultural Sciences (IFAS) is an Equal Opportunity Institution authorized to provide research, educational information and other services

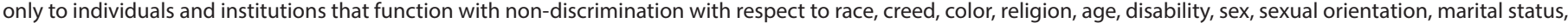

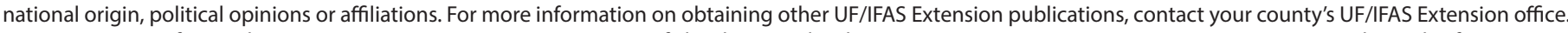
U.S. Department of Agriculture, UF/IFAS Extension Service, University of Florida, IFAS, Florida A \& M University Cooperative Extension Program, and Boards of County Commissioners Cooperating. Nick T. Place, dean for UF/IFAS Extension. 


\section{Algal Leaf Spot: Cephaleuros virescens}

Recognition: Silvery-grey, green, or tan raised spots or blotches with green margins on leaves are caused by algal leaf spot. Heavily infected plants may experience premature yellowing and leaf loss (Figure 3).

Contributing Factors: Abundant moisture, high temperatures, and direct sunlight favor infections, which seem to be most damaging on slow-growing, weakened plants.

Management Recommendations: Use selective pruning to increase air circulation and remove heavily infected leaves. No fungicides are recommended (McLeod Scott 2010).

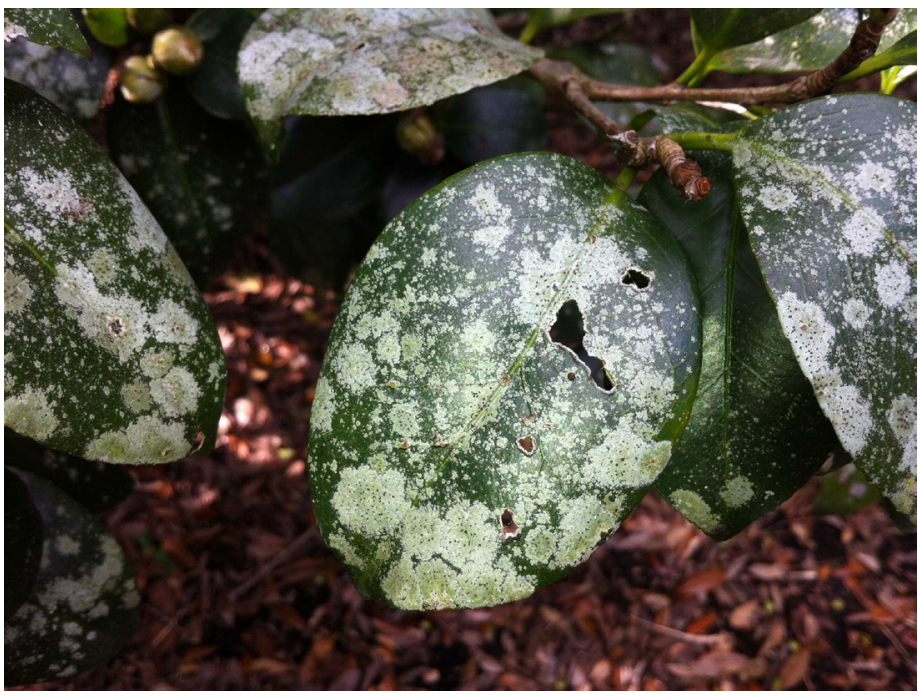

Figure 3. Camellia leaves with algal leaf spot. Credits: Juanita Popenoe, UF/IFAS

\section{Dieback, Twig Blight, or Canker: Colletotrichum gloeosporioides-asexual stage, Glomerella cingulata}

Recognition: New, succulent growth in the spring wilts, and then leaves drop. Entire twigs and shoots may turn brown and die as temperatures increase. Cankers form on older wood at the base of the dead twigs. Persistent active cankers can last for two years on woody stems, providing inoculum that will enter wounds and kill cuttings (Figure 4, $5)$.

Contributing Factors: Most severe in warm, humid conditions. On some species (e.g., C. oleifera), the disease will quickly kill large branches, while other species (e.g., C. hiemalis 'Kanjiro') will heal over the canker. A wound or natural opening is required for infection. Leaf scars are the most common point of entry. The symptoms of wilting and leaf drop may be confused with Phytophthora root rot. If root rot is present, the dieback may be even more severe. The strain of Glomerella that affects camellia will not attack other plants; however, it will attack all species of camellia except C. sinensis. C. sasanqua and C. oleifera are more susceptible than C. japonica. C. sasanqua 'Cleopatra' is particularly susceptible, whereas $C$. japonica 'Charles S. Sargent' and 'Governor Mouton' are particularly resistant.

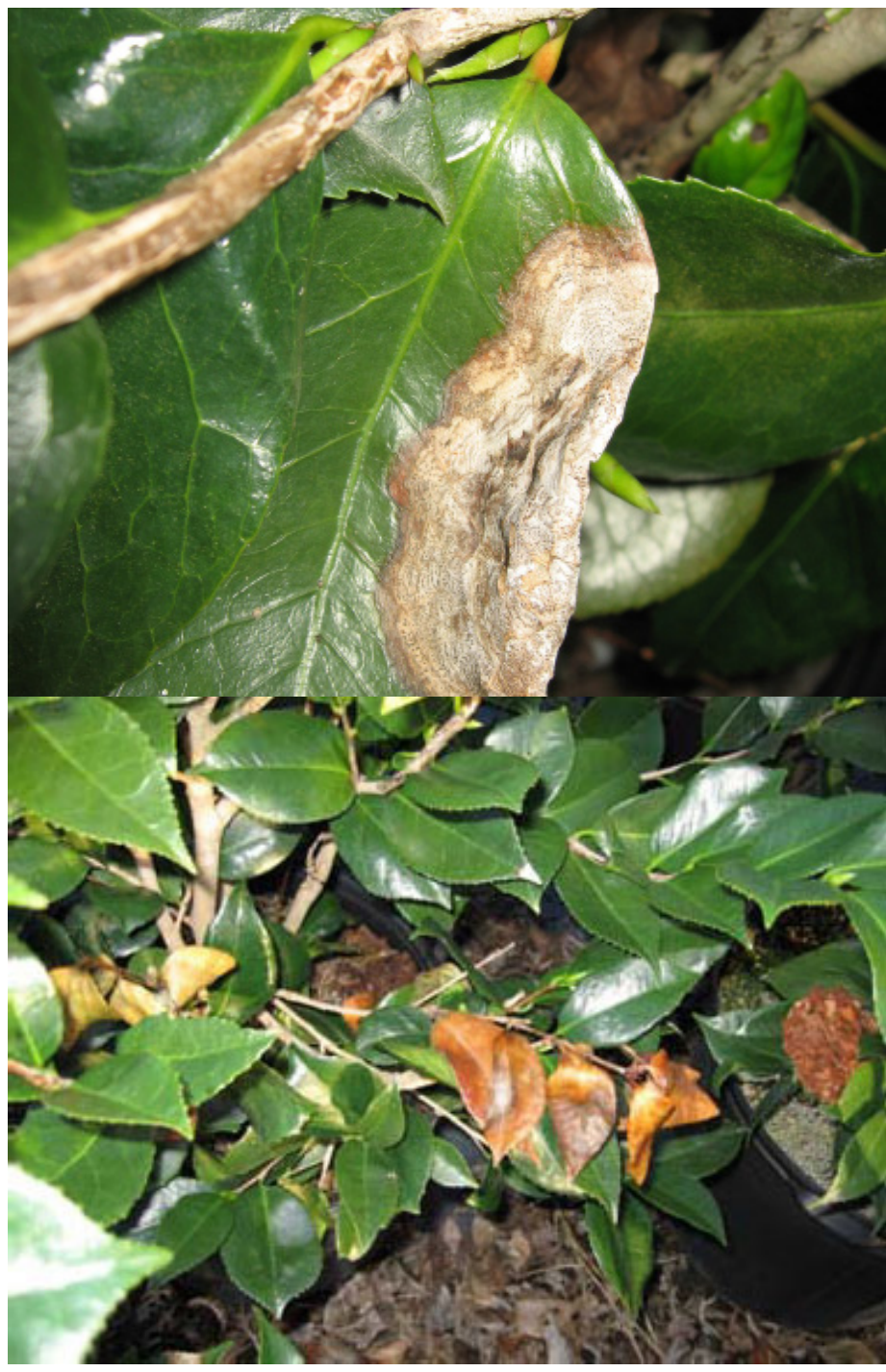

Figures 4 and 5. Leaves exhibiting Glomerella (Figure 4) and canker (Figure 5).

Credits: Juanita Popenoe, UF/IFAS

Management Recommendations: An integrated approach is the best way to manage this disease. Splashing water spreads this disease, so it is best to isolate diseased plants and to minimize overhead irrigation and the length of time foliage and stems are wet. Organize the nursery to increase space between plants in order to improve air movement and sun exposure. Avoid wounding plants and take cuttings from near the tops of healthy plants. Prune out diseased twigs, shoots, and cankers as soon as possible, pruning at least six inches below visibly affected areas. Remove and discard diseased plants and pruning scraps. Disinfect 
pruning tools regularly during pruning and follow good sanitation practices when propagating. Chemical control is targeted in the spring when the old leaves are shedding to protect leaf scars from infection in areas that have had previous dieback. One fungicide application at this time is usually sufficient.

\section{Flower Blight: Ciborinia camelliae}

Recognition: This disease only affects flowers in various stages of development. Irregular tan to light brown spots first appear on petals of expanding flowers and progress to turn the entire petal and flower brown with gray mycelium at the base of the petals near the calyx (Figure 6). Small, hard, black sclerotia develop on the mycelium and allow the fungus to survive in the soil until the next season. Flower blight can be distinguished from cold, wind, or water damage by the growth of the spots, a netted appearance with the veins darker than the surrounding tissue, the presence of sclerotia, and by the scattered appearance of the blighted flowers (cold damage would affect flowers in a larger area).

Contributing Factors: This disease tends to be most severe on C. japonica because the flower development occurs at the same time as the release of spores. C. sasanqua and other species open earlier, often before spores are released, thereby avoiding infection. The disease is also most noticeable on light-colored flowers. Abundant moisture and temperatures around $70^{\circ} \mathrm{F}$ increase the growth of the organism.

Management Recommendations: Chemicals are used only where there is a history of severe infection, and should be targeted to the ground around and under the plants in the fall prior to flowering. A repeat application may be required if flowering is longer than four weeks. Keep the pathogen out of the nursery to avoid establishment of the disease by bringing in only clean plants and flowers. New plants from areas of infection should be bare-root to avoid the chance of sclerotia in the soil. Prune lower branches to increase air movement and to facilitate removal of old flowers. Collect and destroy diseased flowers (Hagan n.d.).

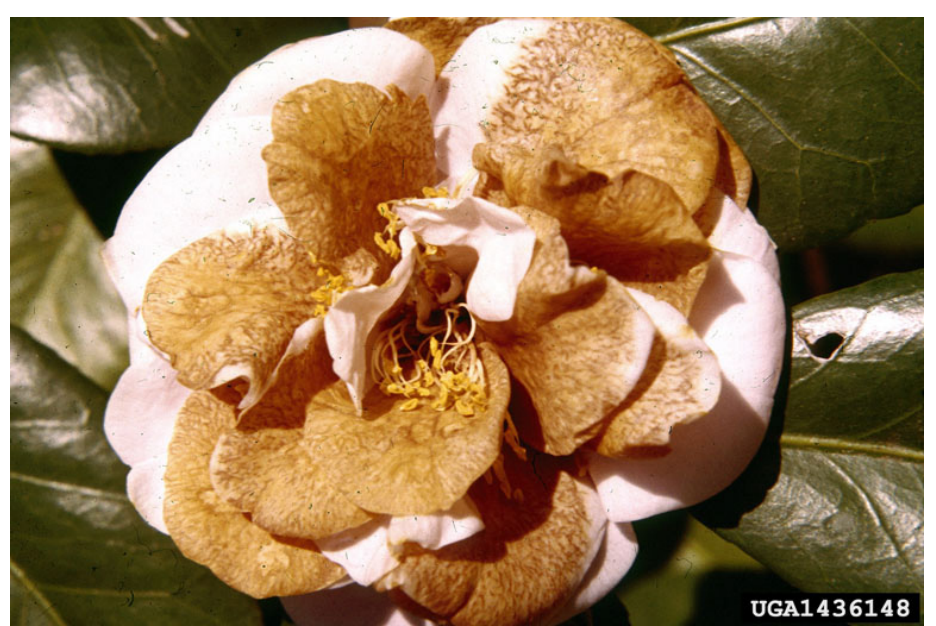

Figure 6. Camellia flower with flower blight.

Credits: Clemson University, USDA Cooperative Extension Slide Series, bugwood.org

\section{Wet Root Rot Diseases (Phytophthora and Pythium spp.)}

Recognition: Above-ground symptoms are poor growth, thinning of the foliage, and yellowing of leaves, with the oldest foliage affected first (Figure 7). These symptoms may be one-sided on the plant. Wet rots cause a soft decay of the outer layers of roots, which can be easily stripped off between two fingers, leaving the firm, white stele intact.

Contributing Factors: The disease is triggered by periods of excessive soil moisture. Conditions that favor disease development include planting too deep, poor drainage, shallow rooting and poor water management.

Management Recommendations: Check roots of nurserygrown plants before planting into the landscape. Provide adequate drainage and reduce irrigation. Apply labeled fungicides if problem is diagnosed early and cultural problems corrected (Dewdney and Burrow 2016).

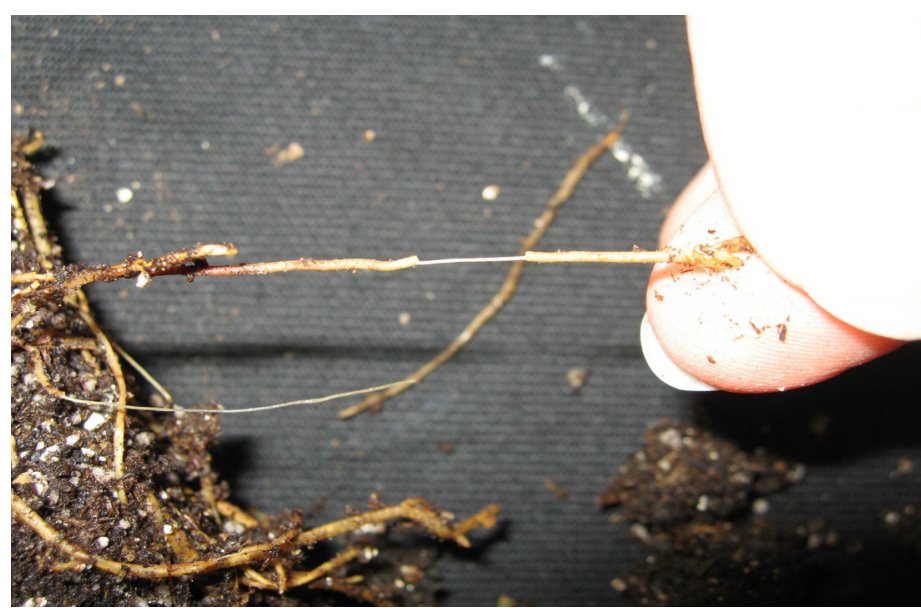

Figure 7. Roots exhibiting wet root rot with slipping roots.

Credits: Juanita Popenoe, UF/IFAS 


\section{Root Rots (Phytophthora, Pythium spp.; Rhizoctonia solani)}

Recognition: The first symptoms noticed are usually in the foliage, which turns a lighter green, somewhat like a nutrient deficiency, then becomes yellow, wilts, and eventually falls off. Infected roots are discolored brown and rotted, with no feeder roots, and occasionally cankers on root crown and lower stem (Figure 8). Plants may become stunted and die quickly if young with a limited root system, or slowly decline if older.

Contributing Factors: Root rots are favored by prolonged periods of saturated soils and moderate temperatures. Spores are moved around in water, soil, container mix, on equipment, and on plant material. Infection may occur when conditions are right, but may not be noticed until hot weather, when the plants have a higher water demand and the lack of roots is limiting. C. japonica and C. reticulata are the most susceptible species of Camellia to Phytophthora, and may be grafted on C. sasanqua, a more resistant species, to improve plant survival.

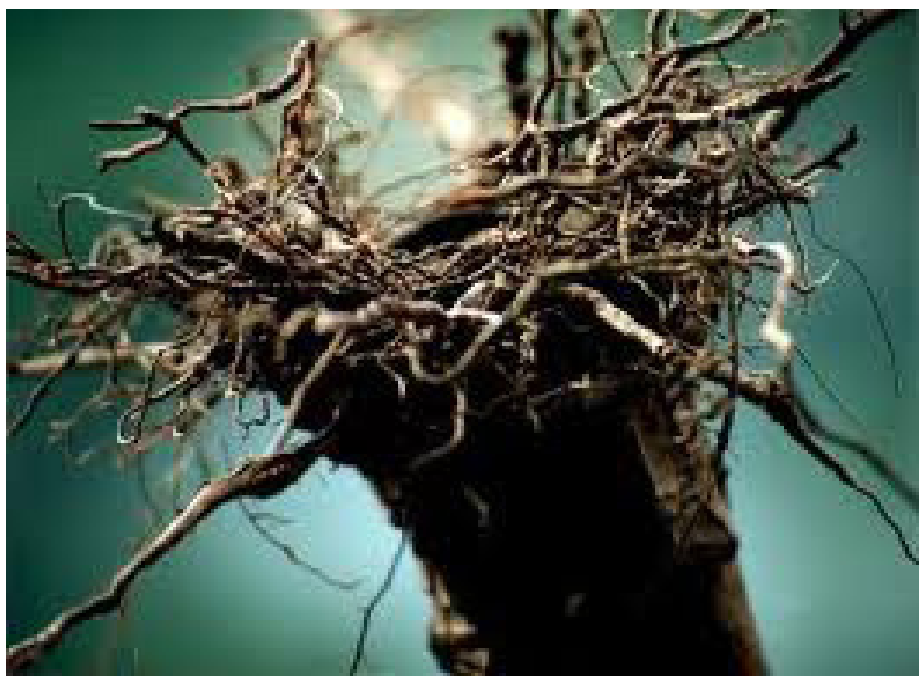

Figure 8. Root of camellia root.

Credits: Fayetteville Camellia Society

Management Recommendations: Avoid overwatering, heavy mixes that retain too much water, placing pots directly on the soil, and standing water. Using a porous material to cover beds (rather than a solid plastic cover) and raising the beds slightly will allow water to drain away and prevent standing water. Always use uninfected potting mix or incorporate composted bark media known to be naturally suppressive to soil pathogens. Use only new or disinfected pots. Disinfect cuttings prior to use and take only from the tops of clean stock plants. Disinfect tools and work surfaces. Do not use untreated recycled irrigation water during propagation or on susceptible cultivars.
Chemical controls do not eliminate the fungus; they only prevent it from active infection. Therefore, repeated applications during periods of heavy rainfall and moderate temperatures may be required (Dewdney and Burrow 2016).

\section{Aphids}

Recognition: Aphids have small, pear-shaped bodies with paired cornicles in rear. They may or may not have wings. Aphids cluster and feed on new growth-flowers, stems, and leaves. Sooty mold grows on honeydew excreted by the aphids. Several kinds and colors of aphids feed on camellia (Figure 9, 10).

Contributing Factors: Aphids occur in the spring and throughout the growing season.

Management Recommendations: Aphid "mummies" are a sign that natural biological control is occurring. High aphid populations may be treated with insecticidal soaps, oils, or approved insecticides (McAuslane 2014).
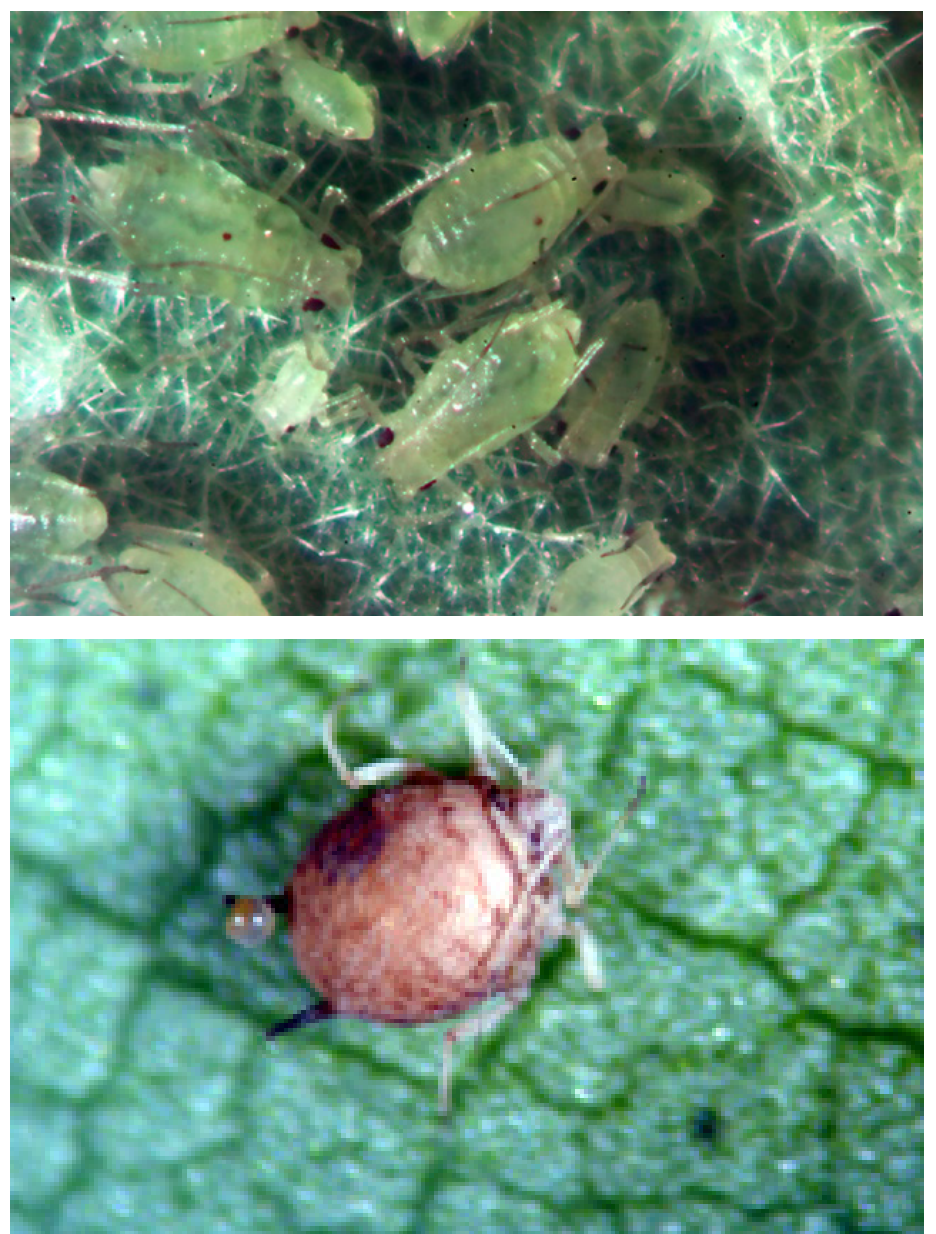

Figures 9 and 10. Aphids (Figure 9) and aphid mummies (Figure 10). Credits: Lance Osborne, UF/IFAS 


\section{Scale}

Recognition: More than 30 species of scale are problematic for camellias, with tea scale being the most common. Variegation on the top of the leaf may be seen with severe infestations. The scale lives on the bottom of the leaf and, in severe infestations, can look fuzzy in a cluster (Figure 11, 12).

Contributing Factors: Eggs are laid when temperatures are $86^{\circ}$ to $91^{\circ} \mathrm{F}$. Depending on temperature, the tea scale life cycle takes between 45 and 65 days. An adult female will lay between 10 and 15 eggs, then shrivel up and die. In warmer climates like Florida, scales reproduce continually throughout the year, but in cooler climates, hatching will often coincide with the warming spring temperatures.

\section{Management Recommendations:}

Cultural. Pruning provides for better coverage of chemical sprays and increased air circulation. In cooler climates, small nonflowering branches growing on major limbs within the interior of the plant should be pruned between February and March.

Chemical. In cooler climates, spring is the best time to apply chemical insecticides, as the danger of cold weather has passed, and egg hatching often coincides with the warming temperatures. It is essential that thorough coverage of the leaf's underside is achieved. The addition of a stickerspreader is an effective way to increase coverage. Repeat applications (2-3) made 7 to 10 days apart is necessary to manage a tea scale infestation. Prior to making pesticide applications, efforts should be made to insure that a current tea scale infestation is not being naturally managed by native parasites. The use of soaps and oils are preferable to insecticides because they are usually less harmful to the natural predators of tea scale. Follow the manufacturer's labeled rate for any product applied to control a pest.

Biological. Several wasps native to the United States, including Aphytis diaspidis and two species of Aspidiotiphagus, have been reported parasitizing tea scales in Florida and Georgia. The female wasp will insert a single egg into the tea scale. Parasitized scales have detectable holes chewed out of their armor by the emerging wasp, and are often associated with patches of necrotic tissue (Miller 2016).

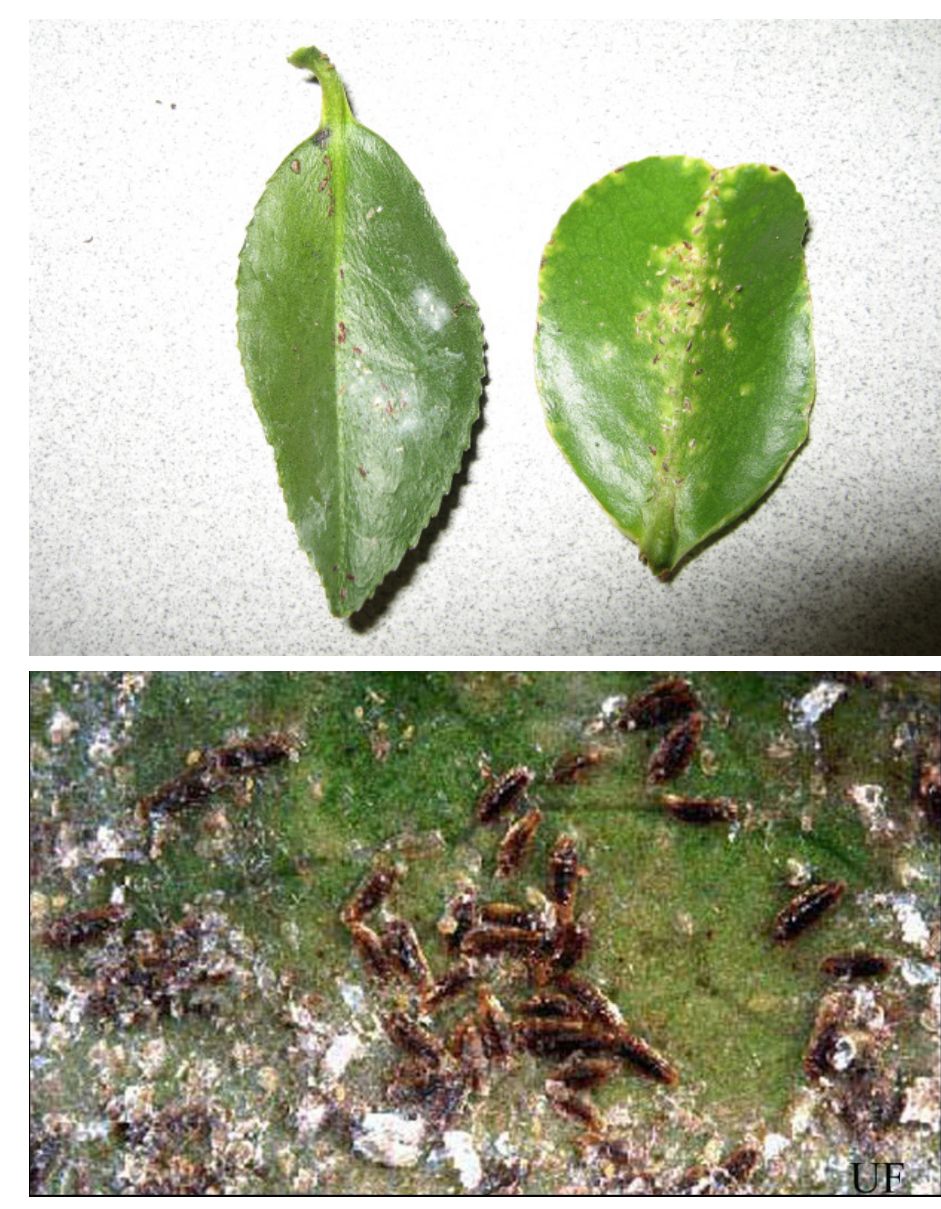

Figures 11 and 12. A leaf contaminated with tea scale (Figure 11). Tea scale infestations (Figure 12).

Credits: Lance Osborne, UF/IFAS

\section{Spider Mites}

Recognition: Tiny (less than 1/50 inch) eight-legged mites are found most commonly on the undersides of leaves. Eggs, cast skins, and silken webs are also signs of mites. Mites feed with piercing-sucking mouthparts, causing the upper sides of leaves to exhibit a stippled or bronzed appearance. Common mite pests of azaleas include both southern red mites and twospotted spider mites. Twospotted spider mites have dark spots on both sides of the abdomen. Southern red mites are named for their bright red color (Figure 13, 14).

Contributing Factors: Southern red mites are most prevalent in cool, moist conditions, whereas two-spotted spider mites prefer hot, dry weather.

Management Recommendations: Scout for mites by knocking branches over a white surface where they will be visible. Check for predaceous mites as well, which are larger and move more quickly. Insecticidal soaps, horticultural oils, or approved miticides may be used to control mites when necessary (Fasulo and Denmark 2009). 

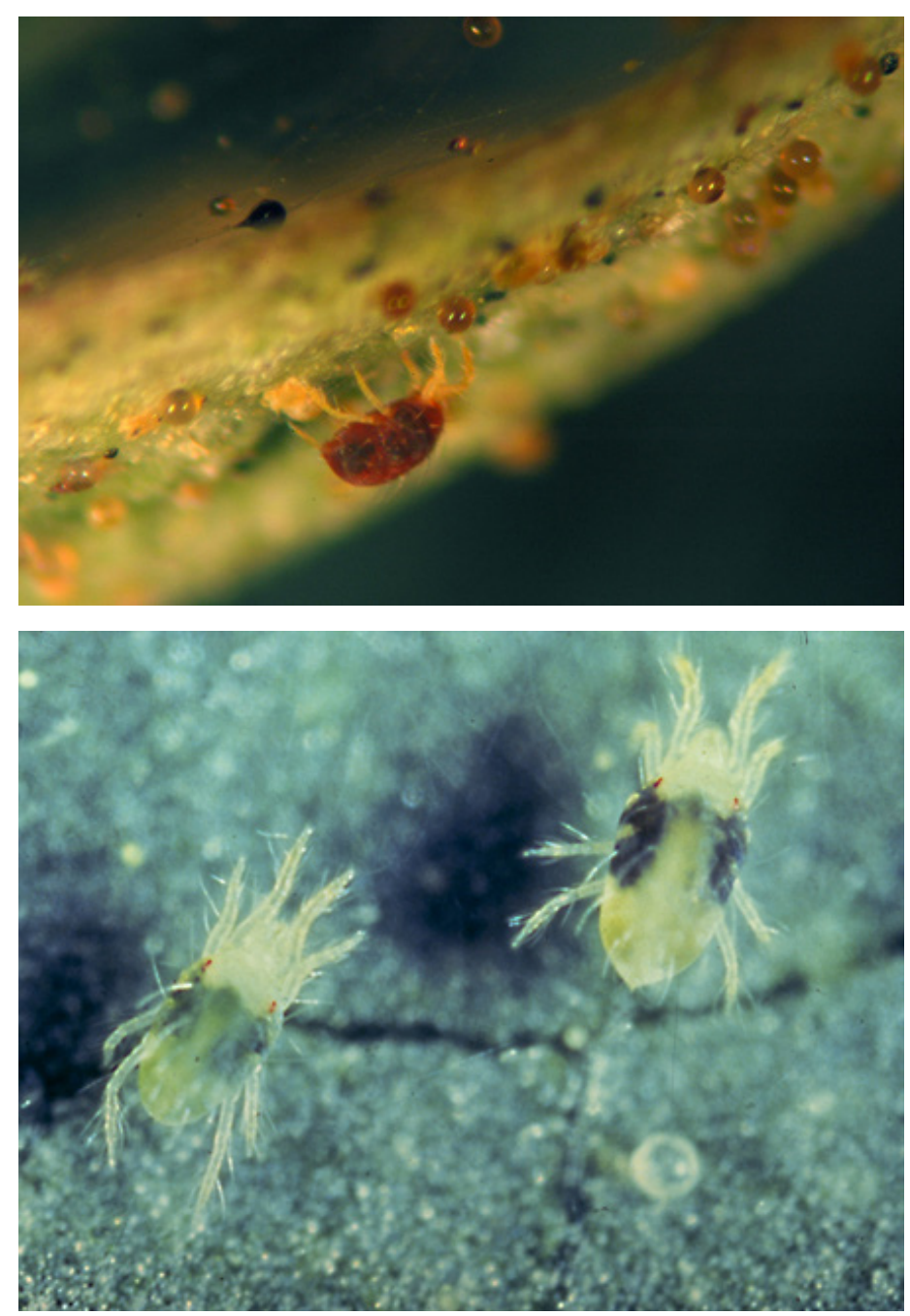

Figures 13 and 14. Southern red mites (Figure 13). Two-spotted spider mites (Figure 14).

Credits: Lance Osborne, UF/IFAS

\section{Nutrient Deficiencies}

\section{Magnesium Deficiency}

Magnesium deficiency is the most common nutritional deficiency on camellia shrubs throughout the state of Florida (Figure 15). Symptoms are most severe on the oldest leaves, and severely deficient plants will drop their leaves. Leaves appear to have broad interveinal or marginal chlorosis, but are not necrotic (Broschat 2017).

\section{Nitrogen Deficiency}

At first, symptoms are most severe on the oldest leaves as a uniform light-green or yellow coloration (Figure 16). As the deficiency becomes more widespread, the entire plant becomes a bright green or yellow color and growth declines sharply (Broschat 2017).

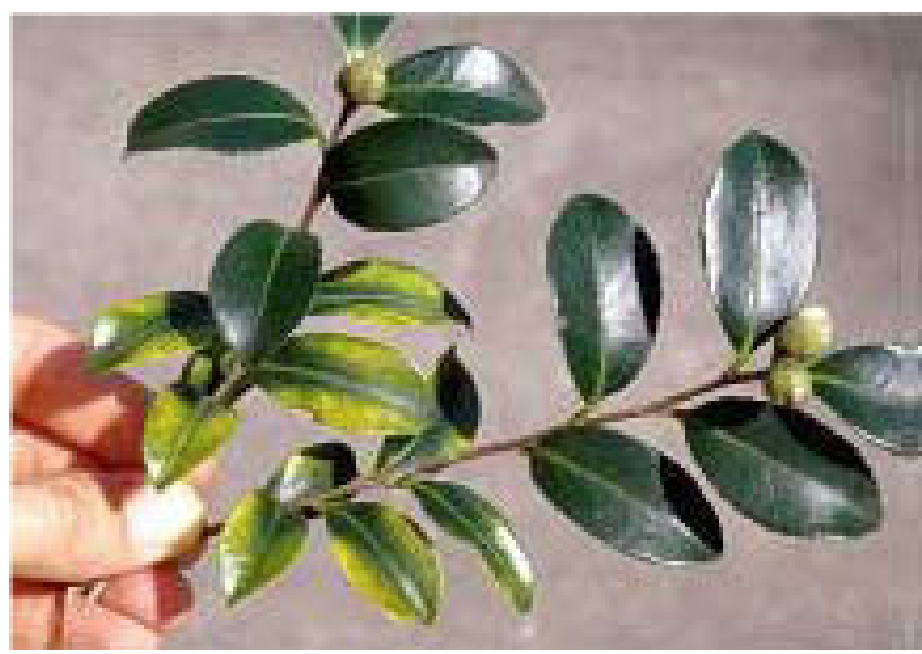

Figure 15. Leaves showing magnesium deficiency. Credits: Florida Department of Agriculture and Consumer Services (FDACS)

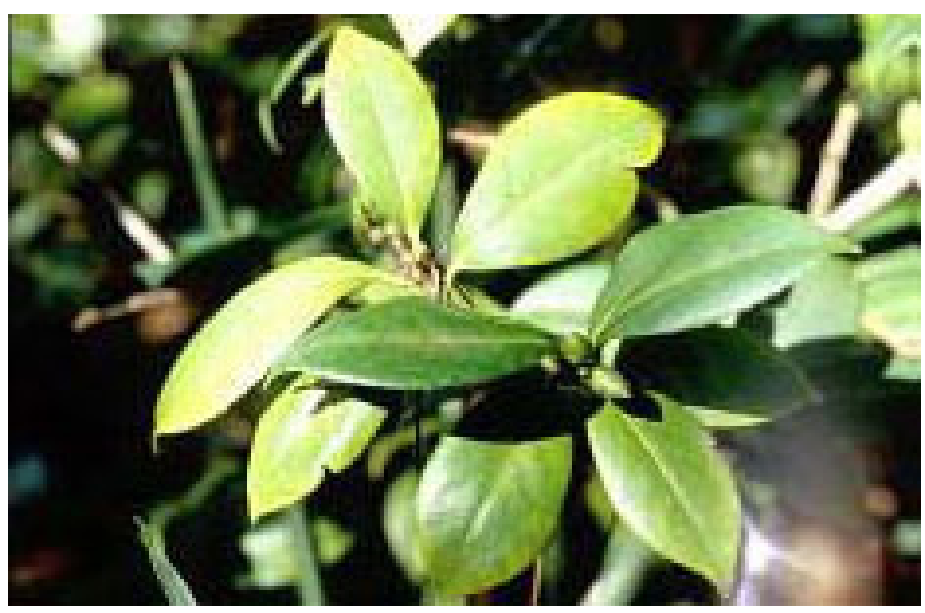

Figure 16. Leaves displaying signs of nitrogen deficiency. Credits: Florida Department of Agriculture and Consumer Services (FDACS)

\section{References}

Broscat, T. K. 2017. Nutrient Deficiency Symptoms of Woody Ornamental Plants in South Florida. ENH1098. Gainesville: University of Florida Institute of Food and Agricultural Sciences. http://edis.ifas.ufl.edu/ep362

Brown, S. P. 2015. Camellias at a Glance. CIR461. Gainesville: University of Florida Institute of Food and Agricultural Sciences. http://edis.ifas.ufl.edu/ep002

Dewdney, M. M. and Burrow, J. D. 2016. Phytophthora Related Diseases for the Dooryard. PP262. Gainesville: University of Florida Institute of Food and Agricultural Sciences. http://edis.ifas.ufl.edu/pp262

Fasulo, T. R. and Denmark, H. A. 2009. "Twospotted spider mite, Tetranychus urticae Koch.” http://entnemdept.ufl.edu/ creatures/orn/twospotted_mite.htm 
Hagan, A. Control of Camellia Petal Blight. Extension

publication ANR-216. Auburn: Alabama A\&M and Auburn

Universities, Alabama Cooperative Extension System.

McAuslane, H. J. 2014. Oleander aphid, Aphis nerii Boyer

de Fonscolombe (Insecta: Hemiptera: Aphididae). EENY247.

Gainesville: University of Florida Institute of Food and

Agricultural Sciences. http://edis.ifas.ufl.edu/in520

McLeod Scott, J. 2010. Algal Leaf Spot. Extension publication TYK 1210. Clemson: Clemson University, Clemson Cooperative Extension.

Miller, C. F. 2016. Tea Scale, Fiorinia theae Green (Insecta: Hemiptera: Diaspididae). EENY250. Gainesville: University of Florida Institute of Food and Agricultural Sciences.

http://edis.ifas.ufl.edu/in522

United States National Arboretum. 2007. "Camellias:

Expanding Their Territory." Last modified January 16.

http://www.usna.usda.gov/Gardens/faqs/Camellia.html 